OPEN ACCESS

Edited by:

Manuela Uda,

Institute of Genetic and Biomedical Research, National Research Council

(CNR), Italy

Reviewed by:

Jürgen Michael Weiss,

University of Lucerne, Switzerland

Valerie Simonneaux,

Centre National de la Recherche

Scientifique (CNRS), France

*Correspondence:

Angela Cristina Nicola

angela.nicola@unesp.br

Rita Cássia Menegati Dornelles rita.dornelles@unesp.br

Specialty section:

This article was submitted to Reproduction,

a section of the journal

Frontiers in Endocrinology

Received: 13 January 2021

Accepted: 06 July 2021

Published: 24 August 2021

Citation:

Nicola AC, Ferreira LB, Mata MM,

Vilhena-Franco $T$, Leite $C M$, Martins AB, Antunes-Rodrigues J,

Poletini MO and Dornelles RCM (2021)

Vasopressinergic Activity of the

Suprachiasmatic Nucleus and mRNA

Expression of Clock Genes in the

Hypothalamus-Pituitary-Gonadal

Axis in Female Aging.

Front. Endocrinol. 12:652733.

doi: 10.3389/fendo.2021.652733

\section{Vasopressinergic Activity of the Suprachiasmatic Nucleus and mRNA Expression of Clock Genes in the Hypothalamus-Pituitary-Gonadal Axis in Female Aging}

\author{
Angela Cristina Nicola ${ }^{1 *}$, Larissa Brazoloto Ferreira ${ }^{1}$, Milene Mantovani Mata ${ }^{2}$, \\ Tatiane Vilhena-Franco ${ }^{2}$, Cristiane Mota Leite ${ }^{3}$, Andressa Busetti Martins ${ }^{4}$, \\ José Antunes-Rodrigues ${ }^{2}$, Maristela Oliveira Poletini ${ }^{5}$ \\ and Rita Cássia Menegati Dornelles ${ }^{1,6 *}$
}

\begin{abstract}
1 Programa de Pós-Graduação Multicêntrico em Ciências Fisiológicas-SBFis/UNESP, Department of Basic Sciences, Araçatuba, Brazil, 2 University of Sao Paulo (USP), School of Medicine of Ribeirão Preto, Department of Physiology, Ribeirão Preto, Brazil, ${ }^{3}$ University of Northern Paraná (UNOPAR), Londrina, Brazil, ${ }^{4}$ Programa de Pós-Graduação Multicêntrico em Ciências Fisiológicas - SBFis/UEL, Department of Physiological Sciences, Londrina, Brazil, ${ }^{5}$ Federal University of Minas Gerais (UFMG), Institute of Biological Sciences, Department of Physiology and Biophysics, Belo Horizonte, Brazil, ${ }^{6}$ São Paulo State University (UNESP), School of Dentistry, Department of Basic Sciences, Araçatuba, Brazil
\end{abstract}

The important involvement of the suprachiasmatic nucleus (SCN) and the activity of vasopressinergic neurons in maintaining the rhythmicity of the female reproductive system depends on the mRNA transcription-translation feedback loops. Therefore, circadian clock function, like most physiological processes, is involved in the events that determine reproductive aging. This study describes the change of mRNA expression of clock genes, Per2, Bmal1, and Rev-erb $\alpha$, in the hypothalamus-pituitary-gonadal axis (HPG) of female rats with regular cycle $(\mathrm{RC})$ and irregular cycle $(\mathrm{IC})$, and the vasopressinergic neurons activity in the SCN and kisspeptin neurons in the arcuate nucleus (ARC) of these animals. Results for gonadotropins and the cFos/AVP-ir neurons in the SCN of IC were higher, but kisspeptin-ir was minor. Change in the temporal synchrony of the clock system in the HPG axis, during the period prior to the cessation of ovulatory cycles, was identified. The analysis of mRNA for Per2, Bmal1, and Rev-erb $\alpha$ in the reproductive axis of adult female rodents shows that the regularity of the estrous cycle is guaranteed by alternation in the amount of expression of Bmal1 and Per2, and Rev-erb $\alpha$ and Bmal1 between light and dark phases, which ceases to occur and contributes to determining reproductive senescence. These results showed that the desynchronization between the central and peripheral circadian clocks contributes to the irregularity of reproductive events. We suggest that the feedback loops of clock genes on the HPG axis modulate the spontaneous transition from regular to irregular cycle and to acyclicity in female rodents.

Keywords: suprachiasmatic nucleus, clock genes, aging, hypothalamus-pituitary-gonadal axis, kisspeptin, vasopressin 


\section{INTRODUCTION}

The physiological rhythms of development, growth, maturity, and aging are regulated in the suprachiasmatic nucleus (SCN) of the mammalian brain. This nucleus exhibits a marked circadian rhythm in neuronal activity $(1,2)$ and neurotransmitter synthesis and release $(3,4)$. In turn, the rhythms are under the regulation of transcription factors generally called clock proteins (5), which are expressed in practically all cell bodies and are the molecular basis of circadian clocks $(6,7)$. Additionally, the rhythms depend on the activity of vasopressinergic neurons present in the SCN dorsomedial portion, from where they project to important areas in relation to reproduction, such as preoptic area (POA), anteroventral periventricular nucleus (AVPv), dorsomedial hypothalamus (DMH), and arcuate nucleus (ARC) (8). At the cellular levels, inhibitory and stimulatory transcriptiontranslation feedback loops regulate clock proteins. Hormones and signals resulting from the activation of neural networks, such as Kisspeptin neurons, are related to fertility and regularity of reproductive cycles and influence these feedback loops $(9,10)$. Changes in the pattern of gonadotropin secretion provide powerful information about physiological control mechanisms, such as the underlying characteristics of pulsatile GnRH secretion (11). Furthermore, GnRH neurons reside mainly in POA and ARC, where neurons are sensitive to kisspeptin, steroids, and circadian regulation of AVP (12-14). Over the last decade, a significant body of evidence has accumulated on the interconnections between circadian clocks and aging (15). Among the theories of aging, the neuroendocrine proposes that programmed functional changes in neurons and associated hormones are central to the aging process (16). Studies in physiological aging animal models have demonstrated that there is higher neuronal activity in brain regions known to be involved with reproduction during the transition to reproductive aging $(17,18)$. The involvement of clock genes in the hypothalamus-pituitary-gonadal axis (HPG) of female rats in the spontaneous transition from regular to irregular cycle and to acyclicity still requires further investigation. It is still unclear to what extent the different physiological phases in life result from effects of the central pacemaker (SCN), peripheral oscillators, both, or on the mechanisms that provide synchronization between the contributing oscillators. In order to characterize the effects of circadian clocks on the aging of the HPG axis, this study evaluated whether the expression of the clock genes on the HPG axis and the vasopressinergic activity of SCN contribute to female reproductive senescence.

\section{MATERIALS AND METHODS}

\section{Characterization of the Animal Model}

The local Ethics Committee of the Universidade Estadual Paulista approved this protocol for Research Involving Animals (Process n. 2014-00269). The animals were treated according to the laboratory principles of animal care (19).
They were housed with ad libitum access to food and water. Four-month-old female Wistar rats (adult-regular cycle in diestrus phase), referred to as the regular cycle group (RC), and 18-month IC group (old-irregular cycle in persistent diestrus phase), referred to as the irregular persistent diestrus cycle group (IC), were obtained from the animal facilities of Universidade Estadual Paulista. The analysis of the increase in the duration of the estrous cycle phases, the decrease in phase variability, and the high frequency of days with leukocyte vaginal cytology characterized the irregularity of the estrous cycle in 18-monthold Wistar rats. The animals in the IC group had persistent diestrus lasting 10-12 days longer, with recurrence in three or four cycles. The adult females showed a regular cycle, and the experimental protocols were performed in the diestrus phase. Only adult multiparous rats with regular estrous cycles and senescent rats with irregular estrous cycles and in persistent diestrus participated in this study, presented in at least three consecutive cycles. The experimental procedures during the dark phase were performed using a light emission diode (LED) emission with emission wavelength of $720 \mathrm{~nm}$ (red light) and intensity less than 1 lux $(20,21)$, controlled by a luximeter (Minipa ${ }^{\circledR}$ digital lux meter MLM-1011).

\section{Collection of Material and Hormone Assays}

Rats from RC and IC groups housed under 12/12 h light/dark cycle, lights on at 7:00 h ( $\mathrm{n}=5-10$ animals/time/group) were killed by decapitation at $6 \mathrm{~h}$ intervals. Blood samples were obtained from the trunk, and brains were rapidly removed and frozen at $-70^{\circ} \mathrm{C}$.

Blood samples collected in heparinized tubes were centrifuged, and the plasma was stored frozen $\left(-20^{\circ} \mathrm{C}\right)$ for hormone assays. Luteinizing hormone ( $\mathrm{LH}$ ) and follicle stimulating hormone (FSH) plasma concentrations were determined using double antibody radioimmunoassay (RIE) with reagents from the National Hormone and Peptide Program (Harbor-UCLA, Torrance, CA, USA). The specific antibodies (anti-rat) used were LH-S10 and FSH-S11 diluted in phosphate buffer with rabbit serum. Standard reference preparations, LH-RP3 and FSH-RP3 $\mathrm{ng} / \mathrm{ml}$ were diluted in $0.1 \%$ phosphate buffer $(0.01 \mathrm{M}, \mathrm{pH}=7.5)$. After the hormones were iodinated and purified (Celso Rodrigues Franci Laboratory, Medical School of Ribeirão Preto-USP, Brazil), the non-specific antibody was also produced in sheep for precipitation of the reaction in the tests. All samples were dosed in duplicate in the same assay to avoid inter-assay variation. The minimum detectable dose was $0.04 \mathrm{ng} / \mathrm{ml}$ for $\mathrm{LH}$ and $0.09 \mathrm{ng} / \mathrm{ml}$ for FSH. Intra-assay coefficients of variation were 1.8 and $3 \%$ for LH and FSH, respectively. The plasma estradiol $\left(\mathrm{E}_{2}\right)$ and progesterone $\left(\mathrm{P}_{4}\right)$ concentrations were measured by Competetive-ELISA using commercial kits (Cayman Chemical Company, MI, USA, for steroids and LSBio, Seattle, USA, for melatonin). $\mathrm{E}_{2}$ detection range: $6.6-4.000 \mathrm{pg} / \mathrm{ml}$ and sensitivity: $20 \mathrm{pg} / \mathrm{ml} . \mathrm{P}_{4}$ detection range: $7.8-1.000 \mathrm{pg} / \mathrm{ml}$ and sensitivity: 10 $\mathrm{pg} / \mathrm{ml}$. All the results were expressed in $\mathrm{ng} / \mathrm{ml}$. 


\section{Fixation of Brain Tissue and Double- Immunolabeling Analysis AVP/cFos}

RC and IC rats were deeply anesthetized with ketamine (ketamine hydrochloride, Syntec ${ }^{\circledR} 80 \mathrm{mg} / \mathrm{Kg} \mathrm{pc} / \mathrm{ip}$ ) and xylazine (xylazine-hydrochloride, Syntec ${ }^{\circledR} 40 \mathrm{mg} / \mathrm{Kg} \mathrm{pc} / \mathrm{ip}$ ) and transcardially perfused with phosphate-buffered saline (PBS), followed by ice-cold 4\% paraformaldehyde at 08:00, 14:00, 20:00, or 02:00 on the day of diestrus. Serial coronal brain sections of $30 \mu \mathrm{m}$ were then cut in four series that represented the anteroposterior length of the SCN. The doubleimmunolabeling of $\mathrm{cFos}$ and argine vasopressin (AVP) was performed on free-floating sections. Sections were first processed for Fos immunoreactivity (anti-Fos antibody, 1:10.000; anti-cFos AB5, PC38, Calbiochem ${ }^{\circledR}$ ) followed by rabbit anti-AVP (1:20.000, anti-AVP, Bachem T4563). The double labeling were performed using the immunoperoxidase method as described previously $(22,23)$. Briefly, for cFos, the following were used: anti-rabbit IgG as secondary antibody (1:200; BA 1000, Vector Laboratories), avidin-biotin kit (1:100; Vector Laboratories), cobalt chloride solution $1 \%(12.5 \mu \mathrm{l} / \mathrm{ml})$, nickel sulfate solution $1 \%(1 \mu \mathrm{l} / \mathrm{ml}), 0.075 \mathrm{mg} / \mathrm{ml} \mathrm{3,3'-}$ diaminobenzidine-HCl (DAB; Sigma-Aldrich, St. Louis, MO, USA), and $0.015 \% \mathrm{H}_{2} \mathrm{O}_{2}$ in $0.1 \mathrm{M} \mathrm{PB}$ buffer. AVP exposure was performed using $\mathrm{DAB}(0.075 \mathrm{mg} / \mathrm{ml})$ and $\mathrm{H}_{2} \mathrm{O}_{2}(0.3 \mu \mathrm{l} / \mathrm{ml}$ of $30 \%$ stock solution in $0.1 \mathrm{M} \mathrm{PBS})$. Next, the sections were mounted on slides (Fisherbrand Superfrost Plus; Fisher Scientific), treated with subbing solution $(0.1 \%$ gelatin and $0.01 \%$ chromium potassium sulfate), and cover slipped with Entellan $\left(\right.$ Merck $\left.^{\circledR}\right)$.

Immuno-double-stained cells were quantified with the aid of a computerized system that included a Leica microscope (Leica DM 4000B LED) equipped with a Leica digital camera (Leica DFC 450) attached to a contrast enhancement device. Representative sections from three to five animals of each experimental group from similar anatomic levels were analyzed (Bregma $-0.60 \mathrm{~mm}$ and $-0.72 \mathrm{~mm}$ were considered) (24). The counting of the double-labeled neurons was performed bilaterally, and neurons with high- and medium-intensity nuclear labeling were considered in this analysis.

\section{Kisspeptin/Fos-Related Antigen (FRA)}

Sections were incubated with the anti-FRA rabbit antibody (K25; Santa Cruz Biotechnology, Santa Cruz, CA, USA), at 1:2,000 for $40 \mathrm{~h}$, biotinylated anti-rabbit goat IgG (Vector Laboratories, Burlingame, CA, USA) at 1:600 for $90 \mathrm{~min}$, and avidin-biotin complex solution at $1: 100$ for $1 \mathrm{~h}$ (Elite ABC kit, Vector Laboratories). A solution of nickel sulphate $(25 \mathrm{mg} / \mathrm{ml}), 3,3^{\prime}-$ diaminobenzidine- $\mathrm{HCl}(\mathrm{DAB}, 0.2 \mathrm{mg} / \mathrm{ml})$, and $0.03 \% \mathrm{H}_{2} \mathrm{O}_{2}(\mathrm{Ni}-$ $\mathrm{DAB})$ was used as the chromogen. Then, sections were then incubated with anti-mouse Kp-10 antibody raised in rabbits (A.C. 564), at 1:10,000 for $40 \mathrm{~h}$, biotinylated anti-rabbit goat IgG (Vector Laboratories) at 1:600 for $90 \mathrm{~min}$, and Elite ABC kit at 1:100 for $1 \mathrm{~h}$. DAB solution was used as chromogen. Brain sections were blindly analyzed for experimental groups under a light microscope with an image analysis system (Motic).
The number of FRA-, kisspeptin-, and FRA/kisspeptinimmunoreactive (ir) neurons was quantified bilaterally in the ARC ( -1.88 to -4.2 from Bregma), according to Paxinos and Watson (24).

\section{Profile Clock Genes mRNA Expression in HPG Axis}

The mRNA quantitative expression for vasopressin $(A V P)$, Period 2 (Per2), Bmal1, and Rev-Erb $\alpha$ was performed in microdissections of the SCN, preoptic area (POA), and mediobasal-hypothalamus $(\mathrm{MBH})$ obtained using the punch technique according to Palkovits (25). Coronal brain sections containing the POA, SCN, and $\mathrm{MBH}$ according to the Paxinos and Watson (24) atlas were obtained in a cryostat (Leica ${ }^{\circledR} 3050 \mathrm{~S}$ ) at $-20^{\circ} \mathrm{C}$ (25). For the POA, a $1,500 \mu \mathrm{m}$ section was obtained starting at approximately $+0.48 \mathrm{~mm}$ from the bregma. A single slice of 600 $\mu \mathrm{m}$, immediately after the POA, was made to the SCN from $-0.48 \mathrm{~mm}$ posterior to the bregma and two subsequent $1,000 \mu \mathrm{m}$ slices from $-1.72 \mathrm{~mm}$ posterior to the bregma for the $\mathrm{MBH}$. The POA and SCN were dissected with 1.5 and $1.0 \mathrm{~mm}$ diameter needles, respectively. The SCN and $\mathrm{MBH}$ were dissected medially to the third ventricle. The $\mathrm{MBH}$ was dissected bilaterally using a 1-mm "square puncher". All isolated regions were stored in RNA later $^{\circledR}$ (Sigma-Aldrich) solution at $-70^{\circ} \mathrm{C}$ until RNA extraction. After pituitary removal, the adenohypophysis was isolated, stored in RNAse-free Eppendorf tubes, and frozen in liquid nitrogen. Ovaries were isolated from with the adipose tissue and subsequently frozen in liquid nitrogen. The structures were kept at $-70^{\circ} \mathrm{C}$ until RNA extraction.

\section{RNA Extraction, cDNA Synthesis, and qPCR}

Total RNA was isolated using TRIzol reagent (Invitrogen ${ }^{\circledR}$ ) according to the manufacturer's protocol. The RNA concentrations were determined using a Nanodrop 2000c UVVis Spectrophotometer (Thermo Scientific). A concentration of $500 \mathrm{ng} / \mu \mathrm{l}$ of RNA was used for cDNA synthesis using the highcapacity complementary DNA reverse transcription kit (Applied Biosystems). Quantitative real-time PCR for Per2, Bmal1, Reverb $\alpha$, and $A V P$ were performed using a Step One Plus real-time PCR system purchased from Applied Biosystems. The qPCR reactions were performed using two different protocols: TaqMan ${ }^{\circledR}$ for the Bmall gene and SYBR ${ }^{\circledR}$ GreenER ${ }^{\mathrm{TM}}$ for Per2, Rev-erb $\alpha$, and $A V P$. The access number of each gene, respective primer sequences, and concentrations are shown in Table 1. Each experimental cDNA was run in triplicate $(2 \mu \mathrm{l}$ of cDNA per reaction) in 96-well plates. Differences above 0.2 between replicates were automatically excluded. The assays were performed under the following conditions: $10 \mathrm{~min}$ at $95^{\circ} \mathrm{C}$, followed by 40 cycles of $15 \mathrm{~s}$ at $95^{\circ} \mathrm{C}$ and $1 \mathrm{~min}$ at $60^{\circ} \mathrm{C}, 15 \mathrm{~s}$ at $95^{\circ} \mathrm{C}$, and $1 \mathrm{~min}$ at $60^{\circ} \mathrm{C}$ and $15 \mathrm{~s}$ at $95^{\circ} \mathrm{C}$, with a gradual increase of $0.3^{\circ} \mathrm{C}$. Water (instead of cDNA) was used as a negative control. The housekeeping gene for normalizing Per2, Rev-erb $\alpha$, and AVP expression was ribosomal 26S RNA, and for Bmal1 expression was $\beta$-actin (Table 1). The determination of the gene transcript levels in each sample was obtained using the $\Delta \Delta \mathrm{CT}$ method. Per2, Rev-erb $\alpha$, and AVP relative mRNA level in 
TABLE 1 | Sequences and concentrations of primers, and gene access numbers.

Template access numbers

$m$ Per2

(NM_031678.1)

mAVP

(NM_016992.2)

$m$ Rev-erb $\alpha$ (NM_001113422.1)

26S RNA

$m$ Bmal1

(NM_024362.2)

MACTB

(NM_031144.2)
Primers and probes

Forward: 5'-GGTCGAGCAAAGGACCGAC-3' Reverse: 5'-GCTGCTCATGTCCACGTCTT-3'

Forward: 5'-TGCCTGCTACTTCCAGAACTGC-3'

Reverse: 5'-AGGGGAGACACTGTCTCAGCTC-3'

Forward: 5'-ACAGCTGACACCACCCAGATC-3' Reverse: 5'-CATGGGCATAGGTGAAGATTCT-3' 10 M

Forward: 5'-CGATTCCTGACAACCTTGCTA-3' Reverse: 5'-CGTGCTTCCCAAGCTCTATGT-3'

(Rn00577590_m1)

(Rn00667869_m1)
Final concentration

$10 \mu \mathrm{M}$

$10 \mu \mathrm{M}$

$10 \mu \mathrm{M}$

*Inventoried Assay.

the unknown sample was calculated using the $2^{-\Delta \Delta C t}$ method (26). The Bmal1 relative mRNA level was determined using the relative standard curve method (27) with $\beta$-actin as an internal reference. The calibrator group used in both quantifications was $\mathrm{CD}$ group $/ 8 \mathrm{~h}$. All results were expressed in arbitrary units of gene expression.

\section{Statistical Analysis}

The Shapiro-Wilk normality test was used to verify the normal distribution of data. Statistical differences in qPCR, hormonal levels, and immunohistochemistry assays were determined using two-way ANOVA performed on Graph Pad Prism ${ }^{\circledR}$ software (CA, USA), version 7.0 for Windows, followed by the Tukey post-test for multiple comparisons. The Mann-Whitney test was used to determine differences in body mass. Values are presented as the means \pm standard error of mean (S.E.M). P $<0.05$ was considered statistically significant for all comparisons.

\section{RESULTS}

\section{Gonadotropins and Steroids Plasma Concentrations}

To understand the temporal profile of gonadotropin and steroid release in persistent diestrus, analyses of the plasma concentrations of these hormones were made. Statistical analysis of plasma concentrations of FSH and $\mathrm{LH}$ indicated an interaction of age and time of day $\left(\operatorname{axb}_{\mathrm{FSH}}<0.0001, \mathrm{~F}_{(3,31)}=14.13\right.$; and $\left.\operatorname{axb}_{\mathbf{L H}}<0.0001, \mathrm{~F}_{(3,33)}=9.245\right)$. Temporal analysis revealed no changes in the FSH plasma levels of the RC group (Figure 1A). However, the IC group showed higher FSH levels at the light phase compared to dark phase, at 08:00 and 14:00 $\left(\mathrm{p}_{20 \mathrm{~h}}<0.0001 ; \mathrm{p}_{02 \mathrm{~h}}<0.05\right)$, as well as those at 02:00 from those at 20:00 $\left(\mathrm{p}_{02 \mathrm{~h}}<0.05\right)$. Intergroup analysis revealed higher plasma FSH concentration in rats in the IC group at 08:00, 14:00, and 02:00 $(\mathrm{p}<0.0001)$. The results for LH (Figure 1B) in the RC group showed no significant changes in plasma concentrations. For the IC animals, there was a higher plasma concentration of $\mathrm{LH}$ at the beginning of the dark phase relative to the light period $(\mathrm{p}<0.01)$. RC and IC animals were significantly different at 20:00 $(\mathrm{p}<0.01) . \mathrm{E}_{2}$ plasma concentration (Figure 1C) did not show interaction between age and time of day $\left(\operatorname{axb}_{\mathrm{E} 2}=0.5370, \mathrm{~F}_{(3,38)}=\right.$ 0.7361). IC group showed a considerable increase in the $E_{2}$ plasma concentration until the beginning of the dark phase $\left(\mathrm{p}_{20 \mathrm{~h}}<0.05\right)$, while in the RC group, basal estradiol levels were observed on diestrus day. In regard to P4 plasma concentrations, there was an interaction between age and time of day $\left(\operatorname{axb}_{\mathrm{P} 4}<0.05\right.$, $\left.\mathrm{F}_{(3,40)}=4.023\right)$ (Figure 1D). IC rats showed a higher plasma $\mathrm{P}_{4}$ concentration, except the $14 \mathrm{~h}$ (Figure 2D), than $\mathrm{RC}$ rats in the diestrus, which showed the lowest levels of $\mathrm{P}_{4}$. Statistical differences were observed in the IC group at 14:00 compared to 08:00 ( $p<0.01)$, 20:00, and 02:00 ( $\mathrm{p}<0.001)$. In intergroup comparisons, the differences were found at 08:00 ( $p<0.05), 20: 00$, and 02:00 $(\mathrm{p}<0.001)$, and there was an interaction between age and time of day $\left(\operatorname{axb}_{\mathbf{P 4}}<0.05, \mathrm{~F}_{(3,40)}=4.023\right)$.

These results show that during the spontaneous transition from regular to irregular cycle and to acyclicity, there is greater secretion of FSH and $\mathrm{P}_{4}$ and a slight increase in the profile of $\mathrm{LH}$ and $\mathrm{E}_{2}$ secretion in relation to $\mathrm{RC}$ on the day of diestrus.

\section{Circadian Activity of the AVP Neurons in the SCN Nucleus}

This experiment examined the light/dark synchronization of the dorsomedial SCN in persistent diestrus during reproductive aging. Our results showed higher AVP gene expression (Figure 2A) and AVP neuronal activity (Figure 2B) in IC group rats during dark period. RC animals showed higher relative mRNA expression at 02:00 than at 08:00 $(p<0.05)$, while in IC group the increase occurred at 20:00 and 02:00, intra- and intergroup (Figure 2A). In addition, the IC animals showed greater vasopressinergic activity at 20:00 than at 08:00 $(\mathrm{p}<0.05)$ and at 02:00 $(\mathrm{p}<0.001)$, as well as at 14:00 relative to at 02:00 $(\mathrm{p}<0.05)$ and the intergroup at 20:00 $(\mathrm{p}<0.01)$ (Figure 2B). The statistical analysis detected that there was an interaction between age and time of day $\left(\mathrm{axb}<0.05, \mathrm{~F}_{(3,31)}=3.172\right)$. In photomicrographs (Figures $\mathbf{2 C - F}$ ), it is possible to check a greater amount of cFos-labeled double vasopressinergic neurons at 20:00 on the day of diestrus in the dorsomedial portion of the SCN of IC rats (Figures 2E, F) and a smaller amount in RC rats (Figures 2C, D). The results show an increase in SCN dorsomedial neuronal activity, in the dark period, during persistent diestrus. 

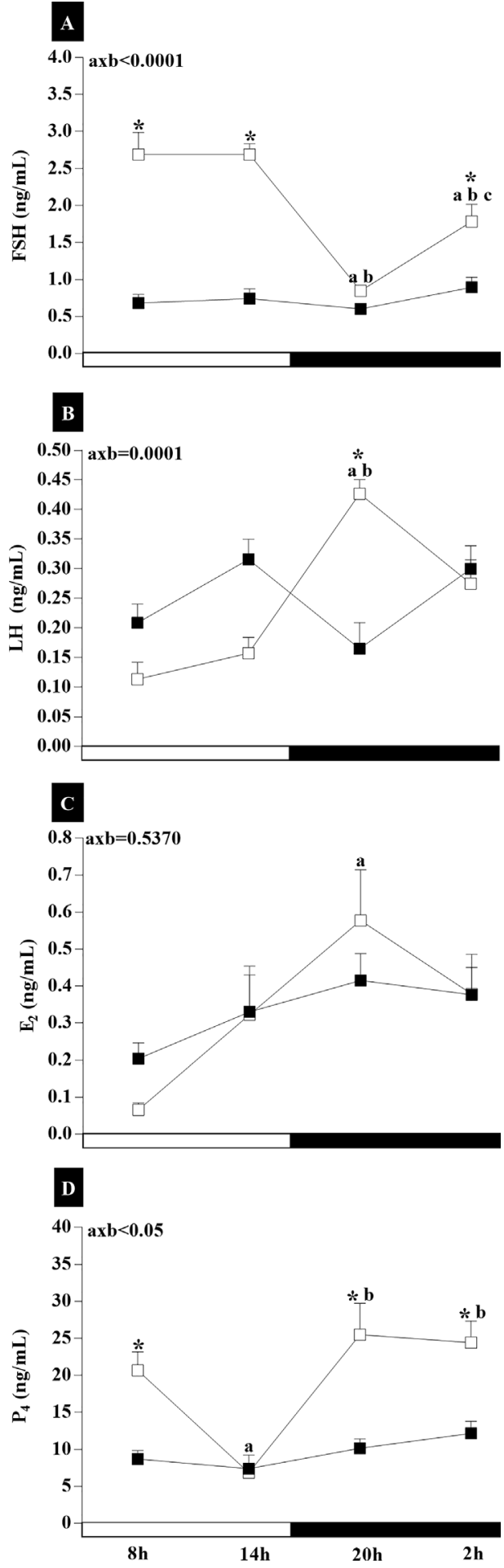

FIGURE 1 | The plasma levels of gonadotropins (A, B) and steroids (C, D) of adult rats with a regular estrous cycle (RC) on diestrus day $(\square)$ and IC group rats with an irregular cycle (IC) in persistent diestrus ( $\square$ ) at 8:00, 14:00, 20:00, and 02:00. The data are expressed as the mean \pm SEM. ${ }^{*} p<0.05$ vs. $\mathrm{RC}$ at the same time; ${ }^{\mathrm{a}} \mathrm{vs} .08: 00,{ }^{\mathrm{b}} \mathrm{vs} .14: 00$, and ${ }^{\mathrm{C}} \mathrm{vs} .20: 00 ; \mathrm{axb}=$ interaction of age and time.

\section{Circadian Activity of the Kisspeptin Neuron in the Arcuate Nucleus}

To evaluate whether there is loss of rhythm in the activity of kiss neurons in the ARC nucleus during the circadian cycle of IC animals, analyses of kisspeptin-ir neurons were conducted. Twoway ANOVA showed that there was no interaction between the two variables, groups (RC and IC), and time (8, 14, 20, and $2 \mathrm{~h}$ ) on the number of FRA-ir neurons in the ARC $\left(\mathrm{axb}=0.4572, \mathrm{~F}_{3.53}=\right.$ 0.8805). There was no statistical difference in the number of FRA-ir neurons in the ARC of both groups (Figure 3A). Analysis of kisspeptin-ir neurons (Figure 3C) showed that there was no interaction between age ( $\mathrm{RC}$ and $\mathrm{IC}$ ) and time of day ( $\mathrm{axb}=$ $\left.0.1961, \mathrm{~F}_{(3.53)}=1.618\right)$. The number of kisspeptin-ir neurons in the ARC was lower $(\mathrm{p}<0.05)$ in IC than in RC group at 08:00, 20:00, and 02:00. In the RC group, differences were observed at 20:00 $(\mathrm{p}<0.05)$ and 02:00 $(<0.0001)$ in relation to at 14:00. There was no interaction between groups (RC and IC) on the number of FRA/Kiss-ir neurons $\left(\mathrm{axb}=0.3975, \mathrm{~F}_{(3,51)}=1.007\right)$, and statistical differences were also not observed in both groups (Figure 3B). There was no interaction between groups (RC and IC) and time (8:00, 14:00, 20:00, and $02: 00 \mathrm{~h})$ on the $\%$ of FRA/Kisspeptin-ir neurons in the ARC ( $\operatorname{axb}=$ $\left.0.2826, \mathrm{~F}_{3.51}=1.306\right)$ (Figure $\left.3 \mathrm{D}\right)$. The results suggest that the circadian signaling of kiss neurons from IC animals is attenuated, contributing to the reduction in the interaction of kiss and GnRH neurons.

\section{Relative Expression of mRNA Clock Genes in HPG Axis}

In this analysis, we aimed to verify if there is an alteration in the expression of clock genes in the HPG axis of senescent rats during the spontaneous transition from regular to irregular cycle and to acyclicity, in relation to cyclic female rats. The results demonstrate temporal changes in circadian rhythm amplitude in 18-month-old animals whose cycles are irregular and remain in persistent diestrus. The experiments demonstrated the synchronization of clock gene transcription with gene activity during the SCN light/dark cycle (Figure 4). Statistical analyses for Bmalland Rev-erb $\alpha$ (Figures 4B, C) in the SCN showed an interaction between age and time of day $\left(\mathrm{axb}_{\mathrm{Bmal}}<0.001, \mathrm{~F}_{(3,105)}=\right.$ 5.913; $\operatorname{axb}_{\text {Rev-erb } \alpha}<0.0001, \mathrm{~F}_{(3,112)}=15.16$; and $\operatorname{axb}_{\mathrm{AVP}}<0.0001$, $\left.\mathrm{F}_{(3,105)}=21.16\right)$. There was greater expression of Per2 at 20:00 (Figure 4A) in the SCN of RC groups. The IC group did not present any statistical difference between the dark and light phase schedules. The intergroup comparison also showed no statistical difference (Figure 4A). Higher Bmal1 mRNA were observed in the light phase of $\mathrm{RC}$ group compared to the dark phase $\left(\mathrm{p}_{14 \times 20 \mathrm{~h}}<0.01\right.$; $\mathrm{p}_{8 \times 20 \mathrm{~h}}<0.0001 ; \mathrm{p}_{8 \times 02 \mathrm{~h}}<0.01$ ) (Figure 4B). However, in the IC group, there was no temporal changes in the Bmall mRNA (Figure 4B). The expression of Rev-erb $\alpha$ mRNA in the SCN of RC group was higher at 14:00 $(p<0.0001)$, decreasing at 20:00 and 02:00 (Figure 4C). On the other hand, IC rats showed increases in Rev-erb $\alpha$ mRNA expression at $20 \mathrm{~h}$ compared at 08:00 $(\mathrm{p}<0.05)$ in the SCN (Figure 4C). Decreased Rev-erb $\alpha$ mRNA occurred at 14:00 $\mathrm{h}(\mathrm{p}<0.01)$, while it increased at 20:00 $\mathrm{h}(\mathrm{p}<0.01)$ in the animals of IC group compared to RC group (Figure 4C). 

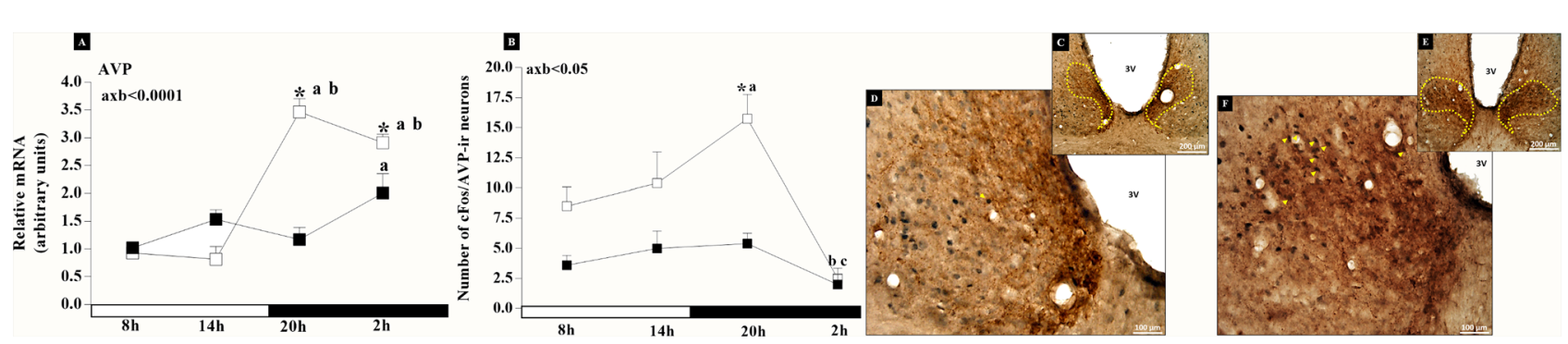

FIGURE 2 | Graphical representation of higher AVP gene expression (A) and AVP neuronal activity (B) observed in rats with irregular cycle (IC group) in persistent diestrus $(\square)$ compared to adult rats with regular estrous cycle (RC) on diestrus day $(\boldsymbol{\square})$. The mean \pm SEM number of cFos/AVP-ir neurons are shown on the graph. ${ }^{*} p<0.05$ vs. RC at the same time interval; ${ }^{2}$ vs. 08:00, ${ }^{b}$ vs.14:00, and ${ }^{C} v s .20: 00 ; a x b=$ interaction of age and time. Photomicrographs of vasopressinergic neurons in the dorsomedial portion of the SCN doubly labeled with cFos (arrows) at 20:00 on diestrus day. Animal RC increased by 200× (C) and 400× (D); animal IC increased by $200 \times(\mathbf{E})$ and $400 \times(\mathbf{F})$.
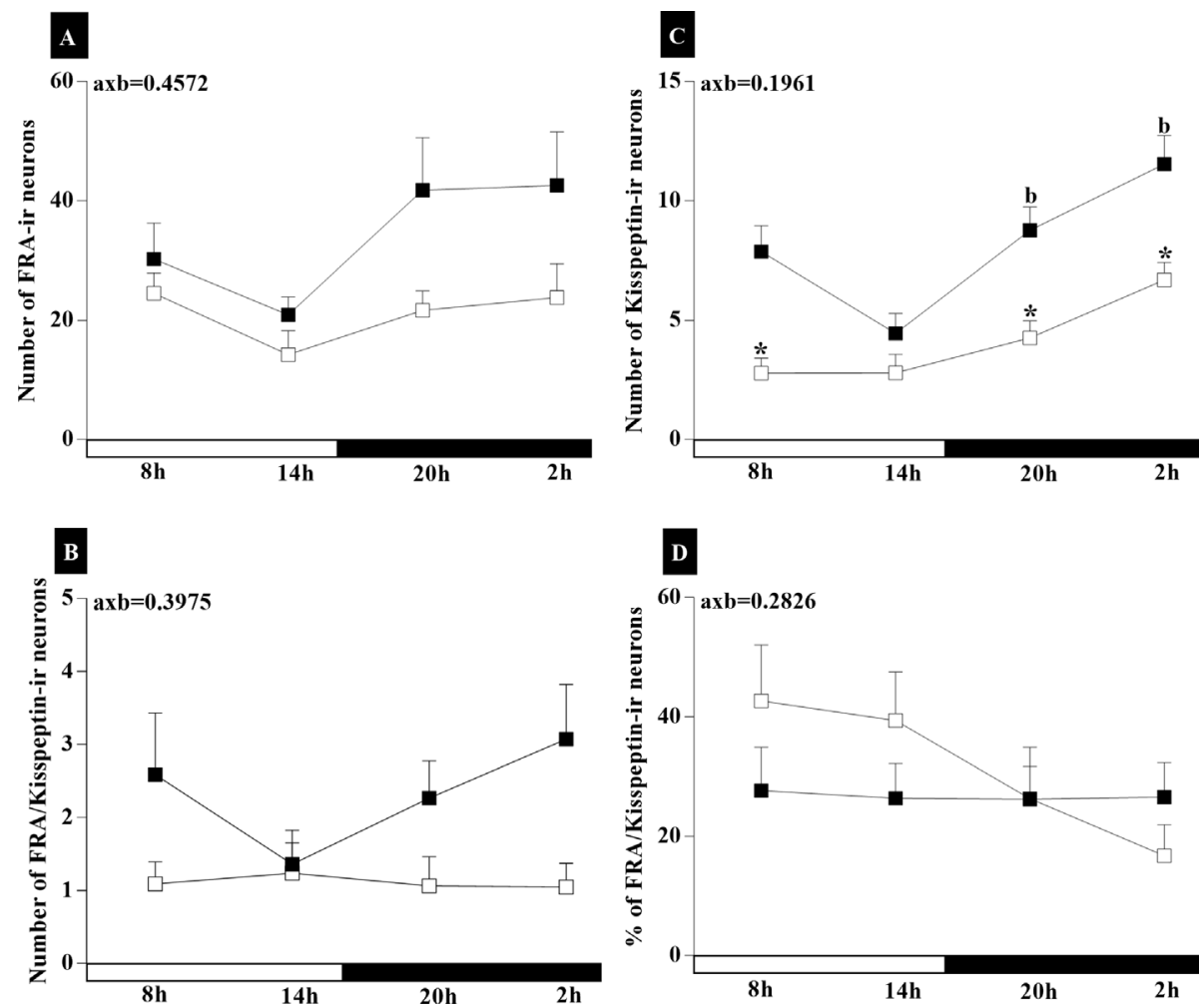

FIGURE 3 | Graphical representation of higher Kisspeptin neuronal activity observed in IC group rats with irregular cycle (IC) in persistent diestrus ( $\square$ ) compared to adult rats with regular estrous cycle (RC) on diestrus day ( $\mathbf{\square})$. The mean \pm SEM number of FRA-ir neurons (A), Kiss-ir neurons (B), FRA/Kiss-ir neurons (C), and \% FRA/Kiss-ir neurons (D) are shown on the graph. ${ }^{*} p<0.05$ vs. RC at the same time interval; ${ }^{b} v s .14: 00 ; a x b=$ interaction of age and time.

The POA analysis of clock genes mRNA indicated an interaction of age and time of day for Per2 and Rev-erb $\alpha$ $\left(\operatorname{axb}_{\text {Per } 2}<0.0001, \mathrm{~F}_{(3,108)}=8,098\right.$; and $\operatorname{axb}_{\text {Rev-erb } \alpha}<0.05, \mathrm{~F}_{(3,130)}=$ $5,105)$ but not for Bmal1 $\left(\mathrm{axb}_{\text {Bmal1 }}=0.0834, \mathrm{~F}_{(3,83)}=2,299\right)$ (Figure 5A). In IC group, the greatest Per2 mRNA was found at 20:00 ( $\mathrm{p}<0.0001)$. Whereas, in the RC group, Per2 expression was higher at 20:00 $\mathrm{h}$ and 02:00 $\mathrm{h}$ compared to 08:00 $\left(\mathrm{p}_{20 \mathrm{~h}}<0.0001\right.$ and $\mathrm{p}_{02 \mathrm{~h}}<0.05$ ) (Figure 5A). In the RC group, the Bmall expression was higher at 02:00 $\mathrm{h}$ compared to that at 08:00 $(\mathrm{p}<0.05)$ and at 20:00 $\mathrm{h}(\mathrm{p}<0.01)$ (Figure 5B). While, in the IC group, lower Bmal1 expression was found at 20:00 $\mathrm{h}$ compared to 14:00 h $(\mathrm{p}<0.05)$. In the IC group, Per2 expression increased at 20:00, while Rev-erb $\alpha$ decreased at 14:00 h. Rev-erb $\alpha$ in the RC group had higher expression at 14:00 $\left(\mathrm{p}_{14 \mathrm{hx} 08 \mathrm{~h}}<0.01\right.$; 


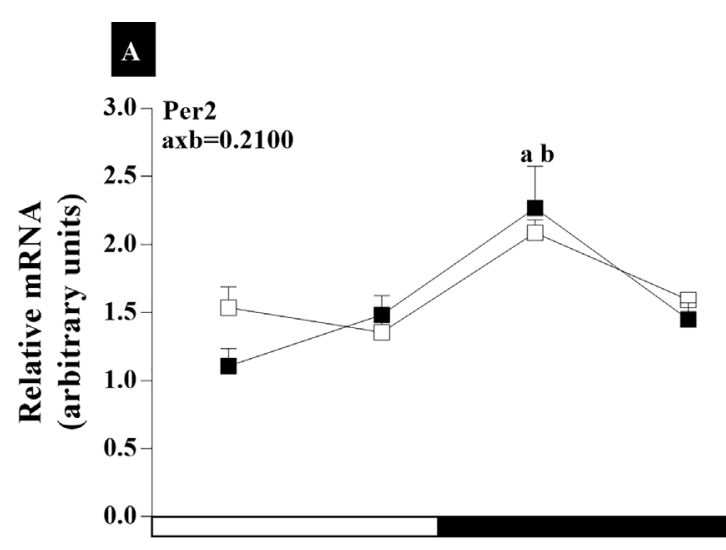

B

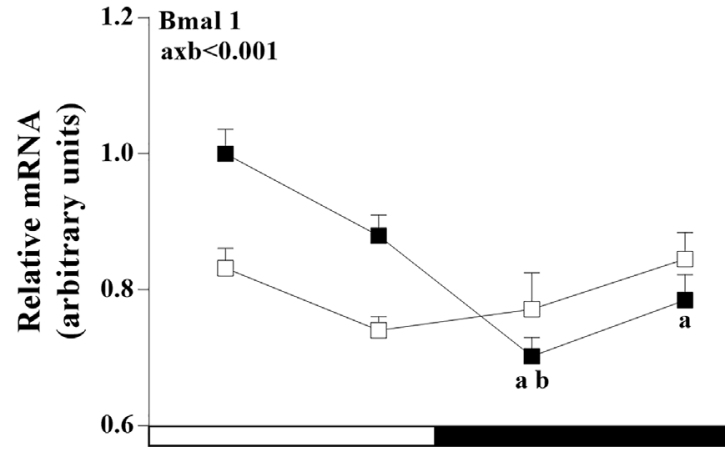

C

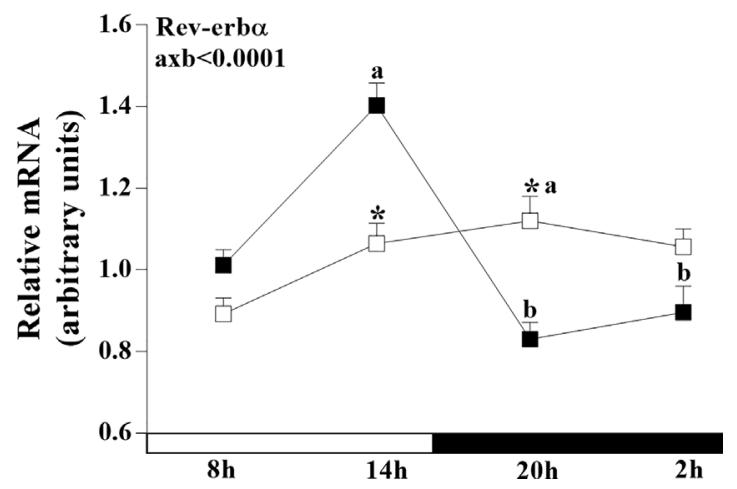

FIGURE 4 | Daily oscillations in relative mRNA expression for Per2, Bmal1, and Rev-erb $\alpha$ in the suprachiasmatic nucleus. Light and dark phases are represented along the $\mathrm{X}$-axis by their respective schedules. Beginning of the light phase at 07:00, when the lights are turned on. The dark phase started at 19:00. All samples were collected at six-hour intervals after the first hour (i.e., 08:00), for $24 \mathrm{~h}$. Light/dark cycle $=12 / 12 \mathrm{~h}$. (A) Relative temporal expression of mRNA for Per2, (B) Bmal1, and (C) Rev-erb $\alpha$ in animals with a regular cycle on diestrus day and irregular cycle in persistent diestrus. * indicates intergroup variation at the same time: $(\boldsymbol{\square})$ Regular estrous cycle on diestrus day $\times(\square)$ irregular cycle in persistent diestrus. Letters indicate temporal variation within the group. ${ }^{\mathrm{a} v}$ v. $8: 00$; ${ }^{\mathrm{b}}$ vs. $14: 00$, and ${ }^{\mathrm{c}}$ vs. $20: 00$. $a x b=$ age and time of day interaction. $n=3-7$. Replicates with a variation above 0.2 were automatically excluded from the groups. $\Delta \Delta \mathrm{Ct}$ for Per2 and Rev-erb $\alpha$; relative standard curve for Bmal1.

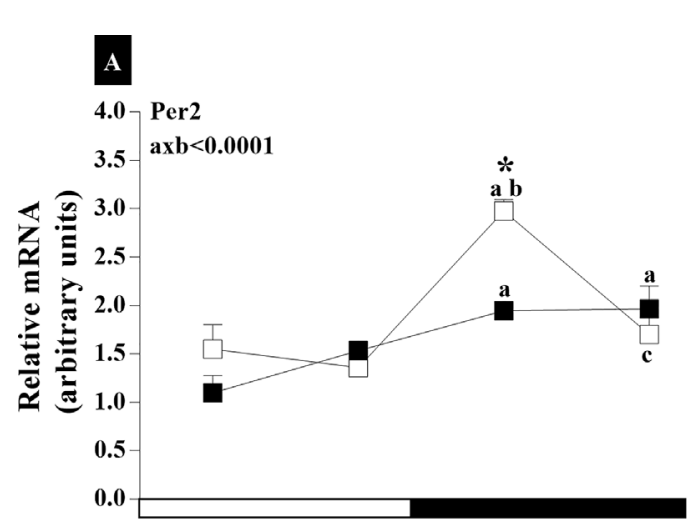

B

$1.4-$ Bmal 1

$\mathbf{a x b}=\mathbf{0 . 0 8 3 4}$

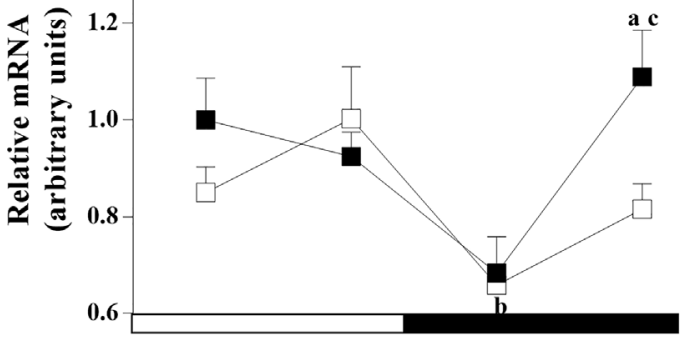

C

$2.0\urcorner$ Rev-erb $\alpha$

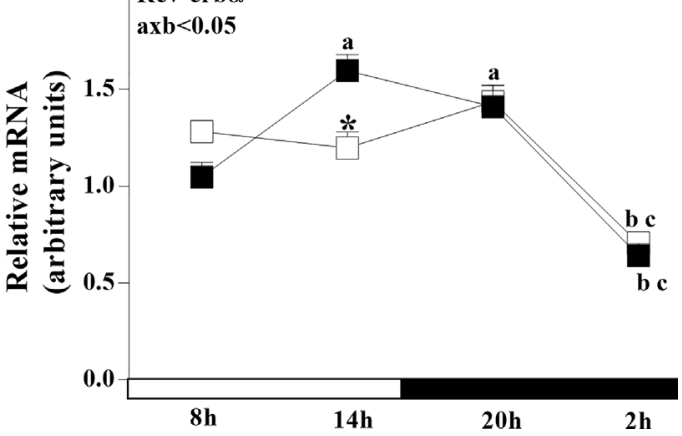

FIGURE 5 | Daily oscillations in relative mRNA expression for Per2, Bma/1, and Rev-erb $\alpha$ in the preoptic area. Light and dark phases are represented along the $\mathrm{X}$-axis by their respective schedules. Beginning of the light phase at 07:00, when the lights are turned on. The dark phase started at 19:00. All samples were collected at six-hour intervals after the first hour (i.e., 08:00), for $24 \mathrm{~h}$. Light/dark cycle $=12 / 12 \mathrm{~h}$. (A) Relative temporal expression of mRNA for Per2, (B) Bmal1, and (C) Rev-erb $\alpha$ in animals with a regular cycle on diestrus day and irregular cycle in persistent diestrus. ${ }^{*}$ indicates intergroup variation at the same time: $(\square)$ Regular estrous cycle on diestrus day $\times(\square)$ Irregular cycle in persistent diestrus. Letters indicate temporal variation within the group. ${ }^{\mathrm{a} v s .} 8: 00$; ' ${ }^{\mathrm{b}} \mathrm{vs} .14: 00$; and ${ }^{\mathrm{C} v s .} 20: 00$. axb = age and time of day interaction. $n=3-7$; Replicates with a variation above 0.2 were automatically excluded from the groups. $\Delta \Delta \mathrm{Ct}$ for Per2 and Rev-erb $\alpha$; relative standard curve for Bmal1. 
$\left.\mathrm{p}_{14 \mathrm{hx} 02 \mathrm{~h}}<0.001\right)$ and 20:00 $\left(\mathrm{p}_{20 \mathrm{hx} 08 \mathrm{~h}}<0.05 ; \mathrm{p}_{20 \mathrm{hx} 02 \mathrm{~h}}<0.001\right)$ than at 08:00 and 02:00 (Figure 5C). On the other hand, the animals with IC expressed a lower amount of Rev-erb $\alpha$ mRNA, with similar amounts expressed in the light phase and dark phase, with lower amounts at 02:00 $\left(\mathrm{p}_{08 \times 02 \mathrm{~h}}<0.0001 ; \mathrm{p}_{14 \times 02 \mathrm{~h}}<0.001\right.$; $\mathrm{p}_{20 \mathrm{x} 02 \mathrm{~h}}<0.0001$ ), but did not differ from $\mathrm{RC}$ rats at this time.

In the $\mathrm{MBH}$, the $\mathrm{RC}$ group exhibited slightly higher Per2 expression at 02:00 $\mathrm{h}$ compared to $14: 00 \mathrm{~h}(\mathrm{p}<0.01)$ (Figure 6A). In the IC group, there was a decrease in Per2 mRNA at 8:00 $(\mathrm{p}<0.0001), 14: 00 \mathrm{~h}(\mathrm{p}<0.0001)$, and $20: 00 \mathrm{~h}(\mathrm{p}<0.0001)$ (Figure 6A). Bmal1 gene expression was higher at 14:00 $(\mathrm{p}<0.001)$ and $02: 00(\mathrm{p}<0.01)$ than at 20:00 in the $\mathrm{RC}$ group (Figure 6B). Rev-erb $\alpha$ exhibited higher expression in RC rats at 08:00 and 14:00 than at 20:00 and 02:00 $(\mathrm{p}<0.05)$. The IC group showed no time-of-day differences. However, in the group of animals with IC, we found a lower expression of Rev-erb $\alpha$ at 08:00 ( $\mathrm{p}<0.01)$ and 14:00 ( $<<0.0001)$ compared to animals with RC (Figure 6C). An interaction of age and time of day was observed for analyses of Per $2\left(\mathrm{axb}<0.0001, \mathrm{~F}_{(3,90)}=27\right)$ and Rev$\operatorname{erb} \alpha\left(\mathrm{axb}<0.0001, \mathrm{~F}_{(3,106)}=18.04\right)($ Figure 6).

In the adenohypophysis, there were significant interactions of age and time-of-day factors on the expression of Per 2 mRNA $\left(\operatorname{axb}_{\mathrm{Per} 2}<0.0001, \mathrm{~F}_{(3,76)}=10.93\right)$ (Figure 7A). The RC group showed a peak in Per2 gene expression at 20:00 h $\left(\mathrm{p}_{08 \mathrm{~h} \times 20 \mathrm{~h}}<0.0001 ; \mathrm{p}_{14 \mathrm{~h} \times 20 \mathrm{~h}}<0.0001\right)$, while minimal expression was seen at 08:00 h (Figure 7A). In the IC group, Per2 expression was higher at 20:00 $\mathrm{h}$ compared to that at 8:00 $\mathrm{h} \quad(\mathrm{p}<0.05)$ (Figure 7A). However, the expression of Per2 at 20:00 h $(\mathrm{p}<0.0001)$ was lower in senescent females compared to adult female rats (Figure 7A). In both RC and IC groups, Bmal1 mRNA was highest at 8:00 h compared to the times analyzed in this study (Figure 7B). For this gene, no interaction of age and time-of-day factors was observed $\left(\mathrm{axb}=0.3964, \mathrm{~F}_{(3,50)}=1.009\right)$. Rev-erb $\alpha$ gene analysis demonstrated a significant interaction of age and time of day $\left(\mathrm{axb}<0.001, \mathrm{~F}_{(3,90)}=130.3\right)$ (Figure 7C). The RC group (Figure 7C) showed higher Rev-erb $\alpha$ expression at 20:00 than at 08:00 and 02:00 $(\mathrm{p}<0.001)$. The IC group showed higher Rev-erb $\alpha$ expression at 20:00 than at 08:00, 14:00, and 02:00 ( $\mathrm{p}<0.0001)$. Increase in Rev-erb $\alpha$ expression occurred at both times of the dark phase in the IC group (Figure 7C).

In the ovaries, statistical analyses reveled interaction of age and time of day on Per 2 expression $\left(\mathrm{axb}<0.0001, \mathrm{~F}_{(3,71)}=38.62\right)$, on Bmal1 expression $\left(\mathrm{axb}<0.0001, \mathrm{~F}_{(3,58)}=9.448\right)$, and on Reverb $\alpha$ expression $\left(\mathrm{axb}<0.0001, \mathrm{~F}_{(3,90)}=26.28\right)$ (Figure 8). The highest level of Per2 expression in the RC group was at 20:00 $(\mathrm{p}<0.0001)$. The IC group showed lower expression at 08:00 h $(\mathrm{p}<0.0001)$ and reduced expression at 20:00 h $(\mathrm{p}<0.0001)$ (Figure 8A). The animals in the IC group showed higher expression of Per2 at 08:00 h ( $\mathrm{p}<0.05), 14: 00 \mathrm{~h}$, and 02:00 h $(\mathrm{p}<0.0001)$ than the animals in the RC group (Figure $\mathbf{8 A}$ ). Similar temporal differences in the ovarian Bmal1 mRNA were found between the RC and IC groups (Figure 8B). Bmall expression was greater at 08:00 ( $\mathrm{p}_{\mathrm{RC} 14}$ and $20 \mathrm{~h}<0.001$ and pIC14 and $20 \mathrm{~h}<0.0001)$ and lower at 14:00 and 20:00 than at 02:00 ( $\mathrm{p}_{\mathrm{RC} 8}$ and $20 \mathrm{~h}<0.0001, \mathrm{p}_{\mathrm{RC} 14 \mathrm{~h}}<0.05$, and $\mathrm{p}_{\mathrm{IC} 14}$ and $20 \mathrm{~h}<0.0001$ ) (Figure 8B). There was increased Bmall expression at 02:00 h

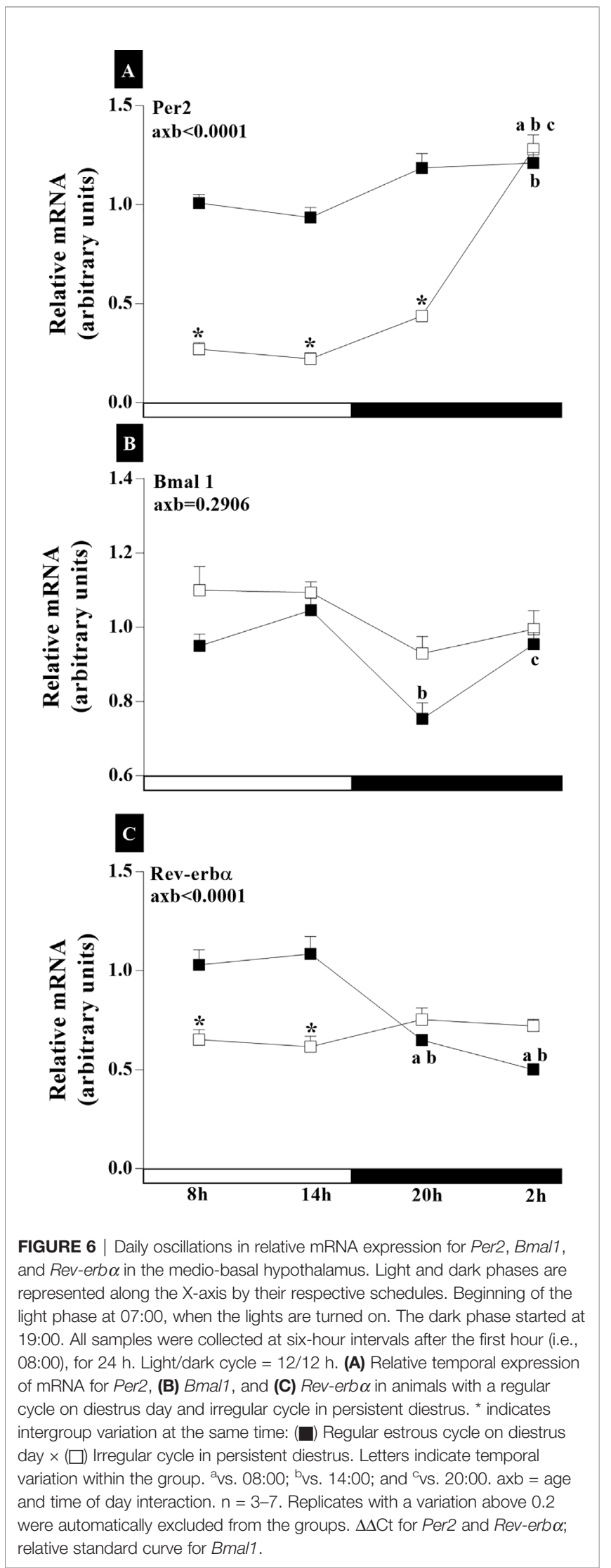




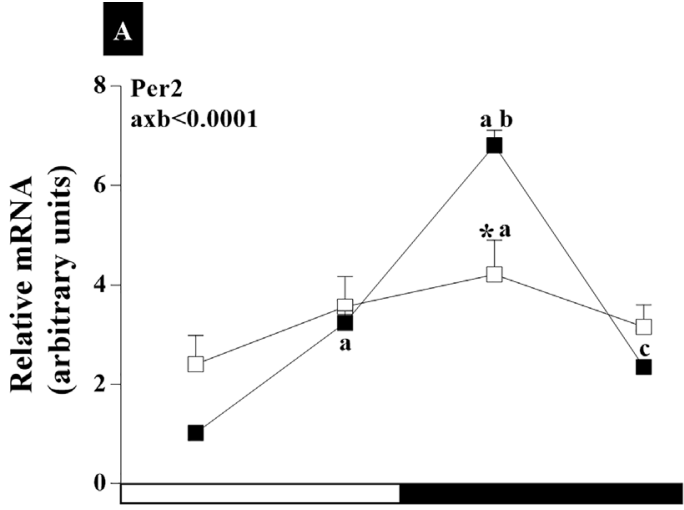

B

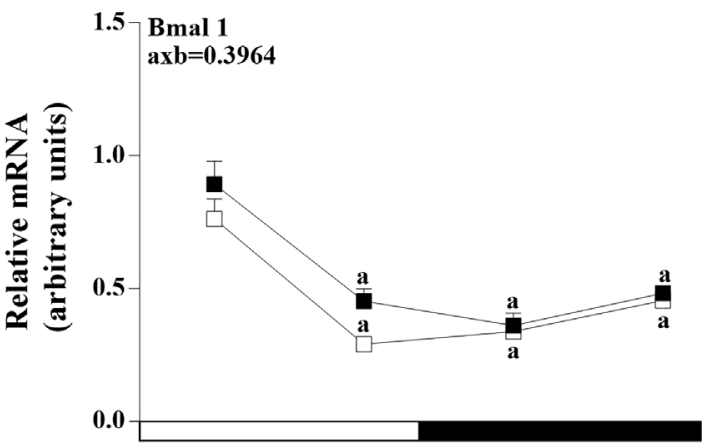

C

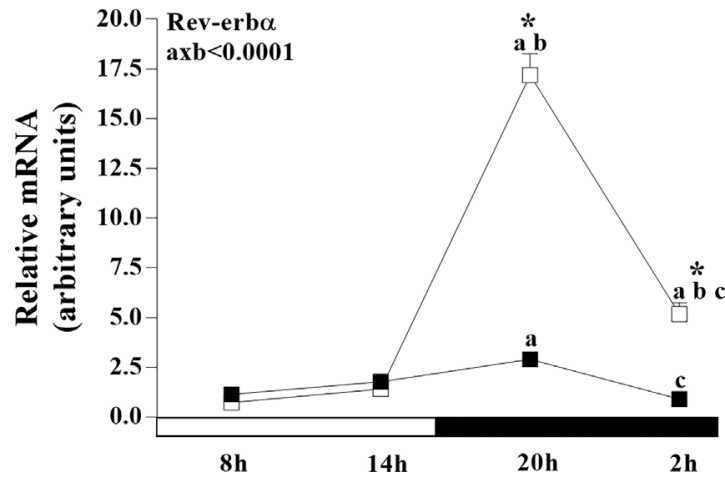

FIGURE 7 | Daily oscillations in relative mRNA expression for Per2, Bmal1, and Rev-erb $\alpha$ in the adenohypophysis. Light and dark phases are represented along the $\mathrm{X}$-axis by their respective schedules. Beginning of the light phase at 07:00, when the lights are turned on. The dark phase started at 19:00. All samples were collected at six-hour intervals after the first hour (i.e., 08:00), for $24 \mathrm{~h}$. Light/dark cycle $=12 / 12 \mathrm{~h}$. (A) Relative temporal expression of mRNA for Per2, (B) Bmal1, and (C) Rev-erb $\alpha$ in animals with a regular cycle on diestrus day and irregular cycle in persistent diestrus. * indicates intergroup variation at the same time: (ద) Regular estrous cycle on diestrus day $\times(\square)$ Irregular cycle in persistent diestrus. Letters indicate temporal variation within the group. ${ }^{2}$ vs. 08:00; ${ }^{b}$ vs. 14:00; and ${ }^{C}$ vs. 20:00. axb = age and time of day interaction. $n=3-7$. Replicates with a variation above 0.2 were automatically excluded from the groups. $\Delta \Delta \mathrm{Ct}$ for Per2 and Rev-erb $\alpha$; relative standard curve for Bmal1.

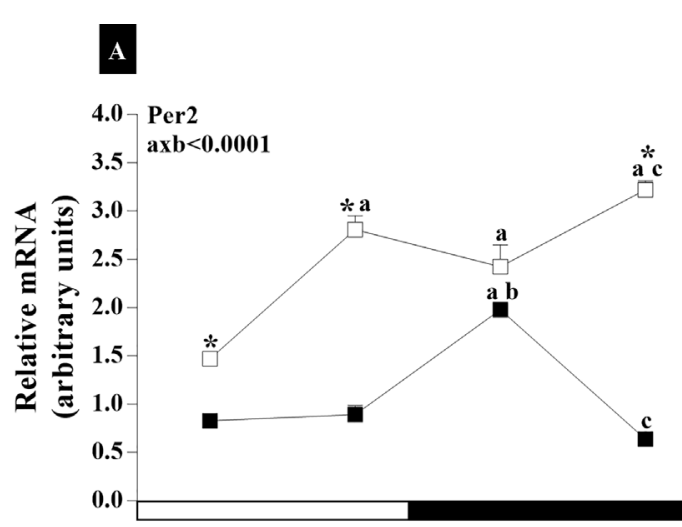

\section{B}

$1.5-$ Bmal 1

$\mathbf{a x b}<\mathbf{0 . 0 0 0 1}$

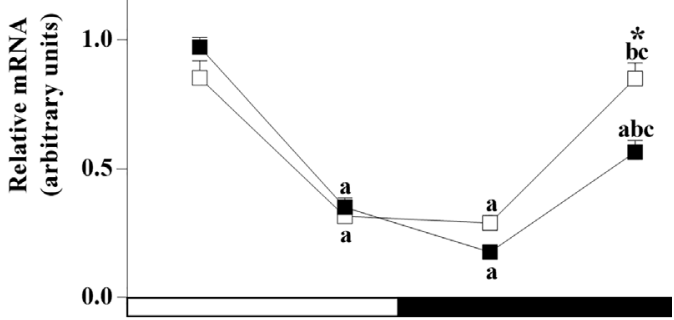

C

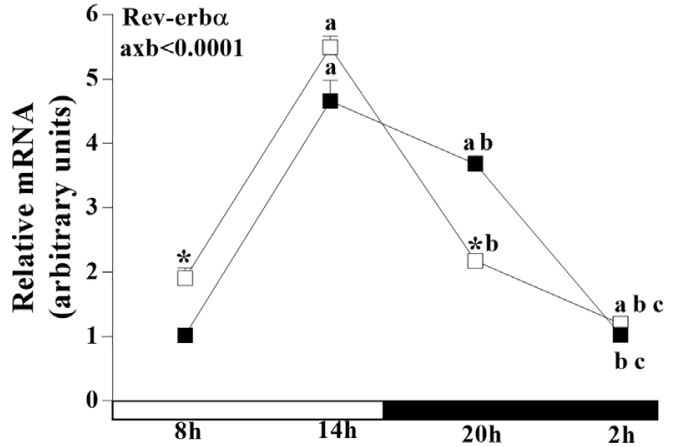

FIGURE 8 | Daily oscillations in relative mRNA expression for Per2, Bmal1, and Rev-erb $\alpha$ in the ovary. Light and dark phases are represented along the $\mathrm{X}$-axis by their respective schedules. Beginning of the light phase at 07:00, when the lights are turned on. The dark phase started at 19:00. All samples were collected at six-hour intervals after the first hour (i.e., 08:00) for $24 \mathrm{~h}$. Light/dark cycle $=12 / 12 \mathrm{~h}$. (A) Relative temporal expression of mRNA for Per2, (B) Bmal1, and (C) Rev-erb $\alpha$ in animals with a regular cycle on diestrus day and irregular cycle in persistent diestrus. ${ }^{*}$ indicates intergroup variation at the same time: $(\square)$ Regular estrous cycle on diestrus day $\times(\square)$ Irregular cycle in persistent diestrus. Letters indicate temporal variation within the group. ${ }^{2} v s$. 08:00; ${ }^{b}$ vs. 14:00; ${ }^{c}$ vs. 20:00. axb = age and time of day interaction. $n=3-7$. Replicates with a variation above 0.2 were automatically excluded from the groups. $\Delta \Delta \mathrm{Ct}$ for Per2 and Rev-erb $\alpha$; relative standard curve for Bmal1. 
$(\mathrm{p}<0.0001)$ in IC group. There was a significant interaction of age and time of day on Bmall expression $(a x b<0.0001)$. The RC and IC groups presented similar gene expression profiles for Rev-erb $\alpha$ (Figure 8C). There was higher Rev-erb $\alpha$ expression at the end of the light phase and the beginning of the dark phase (Figure 8C). Increased Rev-erb $\alpha$ mRNA at 08:00 $\mathrm{h}(\mathrm{p}<0.01)$, while it decreased at $20: 00 \mathrm{~h}(\mathrm{p}<0.01)$, occurred in the animals of IC group (Figure $\mathbf{8 C}$ ).

The results showed irregularity in the expression of Bmal1 and Per2, of Rev-erb $\alpha$ and Bmal1 in the HPG axis, between the light and dark phases, in the period of spontaneous transition from regular to irregular cycle and to acyclicity.

\section{DISCUSSION}

In this study, we observed that clock genes expression rates varied between light and dark phases on the HPG axis, as well as SCN neuronal AVP activity in the persistent diestrus of senescent females compared to the diestrus of adult females. Remarkably, these results are important because the synchronization between neural, endocrine, and neuroendocrine signals, coordinated by the SCN and HPG axis, is important for the occurrence and maintenance of reproduction in mammals $(28,29)$. Also noteworthy is the circadian rhythm for the synthesis activity of vasopressin-releasing neurons in the SCN and its participation in the communication of suprachiasmatic cells. However, the capacity of circadian rhythm regulator genes seems to be diminished during the senescence period. In this sense, studies in the late 1990s showed the importance of the SCN in regulating the circadian system in aged organisms (30-32). We detected higher nocturnal gene expression of $A V P$ and neuronal activity in the SCN, mainly in females with irregular estrous cycle and reproductive senescence, when compared to adult female rats in the diestrus phase of the regular cycle. However, there was found a smaller number of kisspeptinergic neurons in the ARC of IC rats. We highlight here the studies carried out by Padilla et al. (33), showing that only female rodents have kisspeptin neurons in the SCN, some of which corresponded to AVP neurons. These authors also showed that the silenced kisspeptin ARC neurons in female mice resulted in the loss of the normal estrous cycle, remaining in diestrus $(33,34)$. Thus, circadian information from the vasopressinergic and kisspeptinergic neural pathways are essential for the activity of GnRH cells (35-37). Study carried out by our group (38) showed a smaller and constant GnRH content in 18-month-old IC group, similar to the immunostaining data of Kiss neurons in the ARC nucleus. Therefore, our data suggest that communication with $\mathrm{GnRH}$ cells via kisspeptin in ARC may be compromised and lead to a period of persistent diestrus in IC rats. Furthermore, the SCN analysis showed different expression of Per2, Bmall, and Reverb $\alpha$ in the diestrus of RC rats compared to IC rats with persistent diestrus, especially at $20 \mathrm{~h}$, reinforcing the idea of a weakening of the SCN output system (39). These results together reflect the loss of circadian oscillation, which in RC animals is marked by a reduction in the activity of kisspeptin neurons at the end of the light phase with a consequent increase in the dark phase.

An interesting finding of this study was the higher expression of Per2 at 20:00 in the POA of animals in the IC group, similar to that observed in the SCN and coinciding with the greater expression and activity of AVP neurons in the SCN. In addition, aged animals show phase misalignment and lack of rhythmic profile in plasma LH secretion, whose concentration was slightly higher in the dark phase, similar to estradiol concentrations. A subpopulation of the GnRH neurons in the $\mathrm{MBH}$ expresses endogenous clock functions, and gene expression is necessary for continuous and typical $\mathrm{GnRH}$ secretion (40-42). We verified that the relative expression of Per2 did not change in the MHB of the RC rats in diestrus. However, in IC rats in persistent diestrus, the expression of Per2 was lower at 8,14 , and $20 \mathrm{~h}$. These data allow us to suggest linearity of gene expression in the $\mathrm{MBH}$ related to the linearity of the GnRH content observed in rodent females from the IC group, as verified in a previous study of our group (38). We also found differences in the expression of Bmall and Rev-erbo in SCN and $\mathrm{MBH}$ in senescent rats. The absence of circadian rhythmicity of these genes leads us to speculate about the physiological activity of the molecular clock as a determining factor for the absence of ovulatory peaks during female aging. In addition to our data, studies have shown that rodent knockouts of the central Bmall gene are infertile and the mutation/deletion of the gene in the periphery contributes to infertility by compromising the production of steroid hormones, gametogenesis, and abnormalities of delivery and implantation in female $(43,44)$.

Although pituitary cells are under the control of hypothalamic factors, the adenohypophysis cells have a molecular clock capable of measuring time autonomously (45). The molecular clock control in the different cell types of the adenohypophysis provides circadian oscillation in pituitary gonadotrophs, and the daytime rhythm of cell proliferation is synchronized with the estrous cycle in adult rats $(29,46,47)$. Our study demonstrates that these cells are the first extra-SCN elements of the HPG axis to signal changes and contribute to reproductive aging. In IC rats, there was no alteration in the expression of Per 2 and Bmall, although we verified a strong inhibition of Rev-erb $\alpha$ at the same time $(20 \mathrm{~h})$ as there is an increase in $\mathrm{LH}, \mathrm{E}_{2}$ and $\mathrm{P}_{4}$, and lowest in FSH. Interestingly, IC rats exhibit the same response profile for AVP mRNA in the SCN, Rev-erb $\alpha$ in the adenohypophysis, and plasma LH concentration, suggesting that the non-oscillation in the expression of Bmall and Rev-erb $\alpha$ in the SCN at the times analyzed contribute to the increase in the expression of AVP in SCN and plasma LH. In addition, molecular clock components have been detected in the pituitary gland of the rat with autonomous activity and rhythmic LH release, independent of hypothalamic control (48). Perhaps higher plasma $\mathrm{E}_{2}$ and $\mathrm{P}_{4}$ concentrations in IC animals modulate the axis, as estrogen itself alters circadian rhythms, increasing their amplitude $(49,50)$.

Reproductive senescence in laboratory rodents is characterized by follicular atresia, irregular cycles, and steroid hormone 


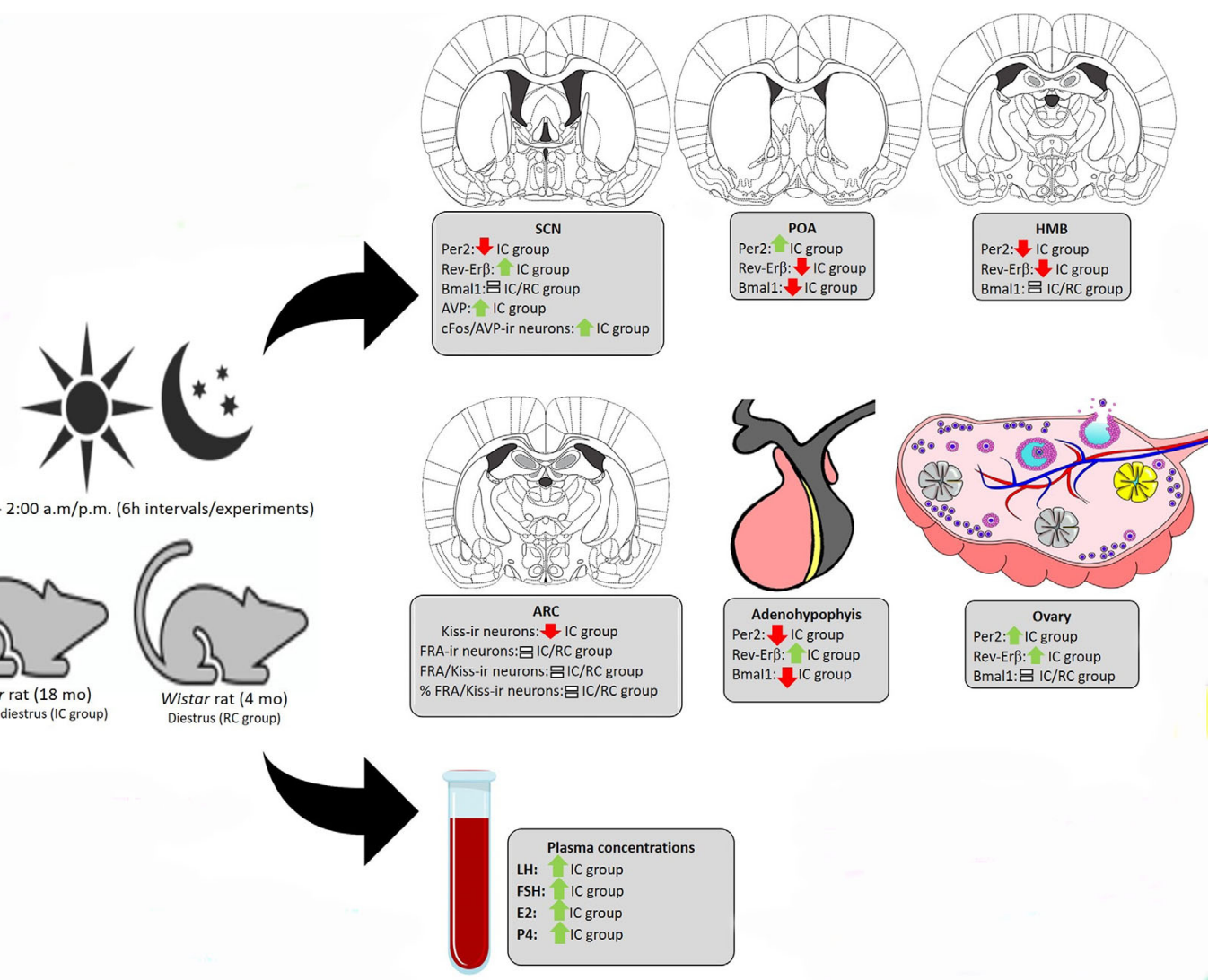

FIGURE 9 | Results summary. Expression profile of clock genes on the HPG axis and activity of SCN AVP neurons and ARC Kiss neurons of rats in periestropause.

fluctuations (51). Remarkably, several studies have shown that there are temporal variations in molecular clock components in ovarian rodent tissues, whose function is related to the timing of gene expression in mature granulosa cells, including genes related to steroidogenesis, gonadotropin responsiveness, and ovulation (52-55). Results of the analyses carried out in the diestrus period of RC rats showed the synchrony of the expression of Per2 and Bmal1 in the ovary and SCN, reinforcing the important synchronization in the expression of clock genes and the integration in the HPG axis modulating the reproductive system. However, this study shows the desynchronization of the expression of these genes in the ovary and that this desynchronization occurs in a subtle way in relation to the SCN and POA. In these animals, transcription of ovarian genes seems to occur autonomously, with the pattern of response of the Per2 transcript contrary to that of $\mathrm{RC}$ animals, suggesting an ovarian temporal window in response to the central stimulus, contributing to persistence in the diestrus phase.

Together, these data support our hypothesis that the feedback loops of clock genes on the HPG axis contribute to modulating the spontaneous transition from regular to irregular cycle and to acyclicity in female rodents (Figure 9). Additionally, it was evidenced that the desynchronization between the central and peripheral circadian clocks contribute to the irregularity of reproductive events.

\section{DATA AVAILABILITY STATEMENT}

The original contributions presented in the study are publicly available. This data can be found at: http://hdl.handle.net/11449/ 152720 and https://repositorio.unesp.br/bitstream/handle/ 11449/152720/nicola_ml_dr_araca_int.pdf?sequence $=$ 3\&isAllowed $=y$.

\section{ETHICS STATEMENT}

The animal study was reviewed and approved by Ethics Committee of the Universidade Estadual Paulista (Process n. 2014-00269).

\section{AUTHOR CONTRIBUTIONS}

$\mathrm{AN}$ : care of experimental animals, data collection, data analysis, data tabulation, discussion of results, and paper 
editing. LF: data collection. MM: gene expression data collection and analysis of results. TV-F: standardization of the cFos/AVP immunohistochemistry analysis in SCN nucleus. CL: standardization of the FRA/Kiss immunohistochemistry and data analysis in Arcuate nucleus. AM: FRA/Kiss data analysis in Arcuate nucleus. JA-R: standardization of gene expression and cFos/AVP immunohistochemistry. MP: data analysis, discussion of results, and paper editing. RD: guidance and monitoring of all experimental steps, data analysis, data tabulation, discussion of results, and paper editing. All authors contributed to the article and approved the submitted version.

\section{REFERENCES}

1. Froy O. Circadian Rhythms, Aging, and Life Span in Mammals. Physiology (2011) 26(4):225-35. doi: 10.1152/physiol.00012.2011

2. Yu EA, Weaver DR. Disrupting the Circadian Clock: Gene-Specific Effects on Aging, Cancer, and Other Phenotypes. Aging (2011) 3(5):479-93. doi: 10.18632/aging.100323

3. Kondratova AA, Kondratov RV. The Circadian Clock and Pathology of the Ageing Brain. Nat Rev Neurosci (2012) 13(5):325-35. doi: 10.1038/nrn3208

4. Reilly DF, Westgate EJ, FitzGerald GA. Peripheral Circadian Clocks in the Vasculature. Arteriosclerosis Thrombosis Vasc Biol (2007) 27(8):1694-705. doi: 10.1161/ATVBAHA.107.144923

5. Fonseca Costa SS, Ripperger JA. Impact of the Circadian Clock on the Aging Process. Front Neurol (2015) 6:43. doi: 10.3389/fneur.2015.00043

6. Panda S, Antoch MP, Miller BH, Su AI, Schook AB, Straume M, et al. Coordinated Transcription of Key Pathways in the Mouse by the Circadian Clock. Cell (2002) 109(3):307-20. doi: 10.1016/S0092-8674(02)00722-5

7. Mellor J. The Molecular Basis of Metabolic Cycles and Their Relationship to Circadian Rhythms. Nat Struct Mol Biol (2016) 23(12):1035-44. doi: 10.1038/ nsmb.3311

8. Bailey M, Silver R. Sex Differences in Circadian Timing Systems: Implications for Disease. Front Neuroendocrinol (2014) 35(1):111-39. doi: 10.1016/ j.yfrne.2013.11.003

9. Simonneaux V, Bahougne T. A Multi-Oscillatory Circadian System Times Female Reproduction. Front Endocrinol (2015) 6:157. doi: 10.3389/ fendo.2015.00157

10. Mendez-Hernandez R, Escobar C, Buijs RM. Suprachiasmatic NucleusArcuate Nucleus Axis: Interaction Between Time and Metabolism Essential for Health. Obesity (2020) 28 Suppl 1:S10-S7. doi: 10.1002/oby.22774

11. Klingman KM, Marsh EE, Klerman EB, Anderson EJ, Hall JE. Absence of Circadian Rhythms of Gonadotropin Secretion in Women. J Clin Endocrinol Metab (2011) 96(5):1456-61. doi: 10.1210/jc.2010-2739

12. Wang L, Moenter SM. Differential Roles of Hypothalamic AVPV and Arcuate Kisspeptin Neurons in Estradiol Feedback Regulation of Female Reproduction. Neuroendocrinology (2020) 110(3-4):172-84. doi: 10.1159/ 000503006

13. Yap CC, Wharfe MD, Mark PJ, Waddell BJ, Smith JT. Diurnal Regulation of Hypothalamic Kisspeptin Is Disrupted During Mouse Pregnancy. J Endocrinol (2016) 229(3):307-18. doi: 10.1530/JOE-16-0086

14. Piet R, Fraissenon A, Boehm U, Herbison AE. Estrogen Permits Vasopressin Signaling in Preoptic Kisspeptin Neurons in the Female Mouse. J neuroscience: Off J Soc Neurosci (2015) 35(17):6881-92. doi: 10.1523/JNEUROSCI.458714.2015

15. Dibner C, Schibler U, Albrecht U. The Mammalian Circadian Timing System: Organization and Coordination of Central and Peripheral Clocks. Annu Rev Physiol (2010) 72:517-49. doi: 10.1146/annurev-physiol-021909-135821

16. Khapre RV, Samsa WE, Kondratov RV. Circadian Regulation of Cell Cycle: Molecular Connections Between Aging and the Circadian Clock. Ann Med (2010) 42(6):404-15. doi: 10.3109/07853890.2010.499134

17. Ferreira LB, de Nicola AC, Anselmo-Franci JA, Dornelles RC. Activity of Neurons in the Preoptic Area and Their Participation in Reproductive

\section{FUNDING}

This study was financed in part by the Coordenação de Aperfeiçoamento de Pessoal de Nível Superior-Brasil (CAPES) Finance Code 001 and São Paulo State Research Foundation (FAPESP: 2012/14464-6).

\section{ACKNOWLEDGMENTS}

The authors thank Dr. Celso R. Franci (FMRP/USP) for the RIA facilities and Fauze de Toledo Ribas for technical assistance.

Senescence: Preliminary Findings. Exp gerontology (2015) 72:157-61. doi: 10.1016/j.exger.2015.10.003

18. Mohawk JA, Green CB, Takahashi JS. Central and Peripheral Circadian Clocks in Mammals. Annu Rev Neurosci (2012) 35:445-62. doi: 10.1146/ annurev-neuro-060909-153128

19. Council NR. Guide for the Care and Use of Laboratory Animals. $8^{a} \mathrm{ed}$. Washington, DC: THE NATIONAL ACADEMIES PRESS (2011).

20. Poletini MO, McKee DT, Kennett JE, Doster J, Freeman ME. Knockdown of Clock Genes in the Suprachiasmatic Nucleus Blocks Prolactin Surges and Alters FRA Expression in the Locus Coeruleus of Female Rats. Am J Physiol Endocrinol Metab (2007) 293(5):E1325-34. doi: 10.1152/ajpendo.00341.2007

21. Sellix MT, Egli M, Poletini MO, McKee DT, Bosworth MD, Fitch CA, et al. Anatomical and Functional Characterization of Clock Gene Expression in Neuroendocrine Dopaminergic Neurons. Am J Physiol Regulatory Integr Comp Physiol (2006) 290(5):R1309-23. doi: 10.1152/ajpregu.00555.2005

22. Mecawi AS, Vilhena-Franco T, Araujo IG, Reis LC, Elias LL, AntunesRodrigues J. Estradiol Potentiates Hypothalamic Vasopressin and Oxytocin Neuron Activation and Hormonal Secretion Induced by Hypovolemic Shock. Am J Physiol Regulatory Integr Comp Physiol (2011) 301(4):R905-15. doi: 10.1152/ajpregu.00800.2010

23. Vilhena-Franco T, Mecawi AS, Elias LL, Antunes-Rodrigues J. Oestradiol Potentiates Hormone Secretion and Neuronal Activation in Response to Hypertonic Extracellular Volume Expansion in Ovariectomised Rats. J Neuroendocrinol (2011) 23(6):481-9. doi: 10.1111/j.1365-2826.2011.02133.x

24. Watson GPC. The Rat Brain in Stereotaxic Coordinates. $6^{a}$ ed. San Diego: Academic Press (2007).

25. Palkovits M. Isolated Removal of Hypothalamic or Other Brain Nuclei of the Rat. Brain Res (1973) 59:449-50. doi: 10.1016/0006-8993(73)90290-4

26. Livak KJ, Schmittgen TD. Analysis of Relative Gene Expression Data Using Real-Time Quantitative PCR and the 2(-Delta Delta C(T)) Method. Methods (2001) 25(4):402-8. doi: 10.1006/meth.2001.1262

27. Larionov A, Krause A, Miller W. A Standard Curve Based Method for Relative Real Time PCR Data Processing. BMC Bioinf (2005) 6:62. doi: 10.1186/14712105-6-62

28. Carbajo-Perez E, Watanabe YG. Cellular Proliferation in the Anterior Pituitary of the Rat During the Postnatal Period. Cell Tissue Res (1990) 261 (2):333-8. doi: 10.1007/BF00318674

29. Oishi Y, Okuda M, Takahashi H, Fujii T, Morii S. Cellular Proliferation in the Anterior Pituitary Gland of Normal Adult Rats: Influences of Sex, Estrous Cycle, and Circadian Change. Anatomical Rec (1993) 235(1):111-20. doi: 10.1002/ar.1092350111

30. Satinoff E, Li H, Tcheng TK, Liu C, McArthur AJ, Medanic M, et al. Do the Suprachiasmatic Nuclei Oscillate in Old Rats as They do in Young Ones? Am J Physiol (1993) 265(5 Pt 2):R1216-22. doi: 10.1152/ajpregu.1993.265.5.R1216

31. Cai A, Scarbrough K, Hinkle DA, Wise PM. Fetal Grafts Containing Suprachiasmatic Nuclei Restore the Diurnal Rhythm of CRH and POMC mRNA in Aging Rats. Am J Physiol (1997) 273(5):R1764-70. doi: 10.1152/ ajpregu.1997.273.5.R1764

32. Li H, Satinoff E. Fetal Tissue Containing the Suprachiasmatic Nucleus Restores Multiple Circadian Rhythms in Old Rats. Am J Physiol (1998) 275 (6):R1735-44. doi: 10.1152/ajpregu.1998.275.6.R1735 
33. Padilla SL, Perez JG, Ben-Hamo M, Johnson CW, Sanchez REA, Bussi IL, et al. Kisspeptin Neurons in the Arcuate Nucleus of the Hypothalamus Orchestrate Circadian Rhythms and Metabolism. Curr biol: CB (2019) 29(4):592-604.e4. doi: 10.1016/j.cub.2019.01.022

34. Yeo SH, Kyle V, Blouet C, Jones S, Colledge WH. Mapping Neuronal Inputs to Kiss1 Neurons in the Arcuate Nucleus of the Mouse. PloS One (2019) 14(3): e0213927. doi: 10.1371/journal.pone.0213927

35. Van der Beek EM, Horvath TL, Wiegant VM, Van den Hurk R, Buijs RM. Evidence for a Direct Neuronal Pathway From the Suprachiasmatic Nucleus to the Gonadotropin-Releasing Hormone System: Combined Tracing and Light and Electron Microscopic Immunocytochemical Studies. J Comp Neurol (1997) 384(4):569-79. doi: 10.1002/(SICI)1096-9861(19970811)384:4<569:: AID-CNE6 $>3.0 . \mathrm{CO} ; 2-0$

36. de la Iglesia HO, Meyer J, Schwartz WJ. Lateralization of Circadian Pacemaker Output: Activation of Left- and Right-Sided Luteinizing Hormone-Releasing Hormone Neurons Involves a Neural Rather Than a Humoral Pathway. J Neurosci: Off J Soc Neurosci (2003) 23(19):7412-4. doi: 10.1523/ JNEUROSCI.23-19-07412.2003

37. Vida B, Deli L, Hrabovszky E, Kalamatianos T, Caraty A, Coen CW, et al. Evidence for Suprachiasmatic Vasopressin Neurones Innervating Kisspeptin Neurones in the Rostral Periventricular Area of the Mouse Brain: Regulation by Oestrogen. J Neuroendocrinol (2010) 22(9):1032-9. doi: 10.1111/j.13652826.2010.02045.x

38. Nicola AC, Leite CM, Nishikava MM, de Castro JC, Anselmo-Franci JA, Dornelles RC. The Transition to Reproductive Senescence Is Characterized by Increase in A6 and AVPV Neuron Activity With Attenuation of Noradrenaline Content. Exp Gerontol (2016) 81:19-27. doi: 10.1016/ j.exger.2016.04.015

39. Ohara T, Nakamura TJ, Nakamura W, Tokuda IT. Modeling Circadian Regulation of Ovulation Timing: Age-Related Disruption of Estrous Cyclicity. Sci Rep (2020) 10(1):16767. doi: 10.1038/s41598-020-73669-x

40. Hickok JR, Tischkau SA. In Vivo Circadian Rhythms in GonadotropinReleasing Hormone Neurons. Neuroendocrinology (2010) 91(1):110-20. doi: $10.1159 / 000243163$

41. Zhao S, Kriegsfeld LJ. Daily Changes in GT1-7 Cell Sensitivity to GnRH Secretagogues That Trigger Ovulation. Neuroendocrinology (2009) 89(4):44857. doi: $10.1159 / 000192370$

42. Tonsfeldt KJ, Chappell PE. Clocks on Top: The Role of the Circadian Clock in the Hypothalamic and Pituitary Regulation of Endocrine Physiology. Mol Cell Endocrinol (2012) 349(1):3-12. doi: 10.1016/j.mce.2011.07.003

43. Boden MJ, Varcoe TJ, Voultsios A, Kennaway DJ. Reproductive Biology of Female Bmal1 Null Mice. Reproduction (2010) 139(6):1077-90. doi: 10.1530/ REP-09-0523

44. Ratajczak CK, Boehle KL, Muglia LJ. Impaired Steroidogenesis and Implantation Failure in Bmall-/- Mice. Endocrinology (2009) 150(4):187985. doi: 10.1210/en.2008-1021

45. Abe M, Herzog ED, Yamazaki S, Straume M, Tei H, Sakaki Y, et al. Circadian Rhythms in Isolated Brain Regions. J Neurosci: Off J Soc Neurosci (2002) 22 (1):350-6. doi: 10.1523/JNEUROSCI.22-01-00350.2002
46. Becquet D, Boyer B, Rasolonjanahary R, Brue T, Guillen S, Moreno M, et al. Evidence for an Internal and Functional Circadian Clock in Rat Pituitary Cells. Mol Cell Endocrinol (2014) 382(2):888-98. doi: 10.1016/j.mce. 2013.11.004

47. Sellix MT. Clocks Underneath: The Role of Peripheral Clocks in the Timing of Female Reproductive Physiology. Front Endocrinol (2013) 4:91. doi: 10.3389/ fendo.2013.00091

48. Lewy H, Naor Z, Ashkenazi IE. Rhythmicity of Luteinizing Hormone Secretion Expressed In Vitro. Eur J Endocrinol (1996) 135(4):455-63. doi: 10.1530/eje.0.1350455

49. Morin LP. Effect of Ovarian Hormones on Synchrony of Hamster Circadian Rhythms. Physiol Behav (1980) 24(4):741-9. doi: 10.1016/0031-9384(80) 90406-0

50. Albers HE, Gerall AA, Axelson JF. Effect of Reproductive State on Circadian Periodicity in the Rat. Physiol Behav (1981) 26(1):21-5. doi: 10.1016/00319384(81)90073-1

51. Van Kempen TA, Milner TA, Waters EM. Accelerated Ovarian Failure: A Novel, Chemically Induced Animal Model of Menopause. Brain Res (2011) 1379:176-87. doi: 10.1016/j.brainres.2010.12.064

52. Fahrenkrug J, Georg B, Hannibal J, Hindersson P, Gras S. Diurnal Rhythmicity of the Clock Genes Per1 and Per2 in the Rat Ovary. Endocrinology (2006) 147(8):3769-76. doi: 10.1210/en.2006-0305

53. Karman BN, Tischkau SA. Circadian Clock Gene Expression in the Ovary: Effects of Luteinizing Hormone. Biol Reprod (2006) 75(4):624-32. doi: 10.1095/biolreprod.106.050732

54. He PJ, Hirata M, Yamauchi N, Hashimoto S, Hattori MA. Gonadotropic Regulation of Circadian Clockwork in Rat Granulosa Cells. Mol Cell Biochem (2007) 302(1-2):111-8. doi: 10.1007/s11010-007-9432-7

55. Sellix MT. Circadian Clock Function in the Mammalian Ovary. J Biol rhythms (2015) 30(1):7-19. doi: 10.1177/0748730414554222

Conflict of Interest: The authors declare that the research was conducted in the absence of any commercial or financial relationships that could be construed as a potential conflict of interest.

Publisher's Note: All claims expressed in this article are solely those of the authors and do not necessarily represent those of their affiliated organizations, or those of the publisher, the editors and the reviewers. Any product that may be evaluated in this article, or claim that may be made by its manufacturer, is not guaranteed or endorsed by the publisher.

Copyright (c) 2021 Nicola, Ferreira, Mata, Vilhena-Franco, Leite, Martins, AntunesRodrigues, Poletini and Dornelles. This is an open-access article distributed under the terms of the Creative Commons Attribution License (CC BY). The use, distribution or reproduction in other forums is permitted, provided the original author(s) and the copyright owner(s) are credited and that the original publication in this journal is cited, in accordance with accepted academic practice. No use, distribution or reproduction is permitted which does not comply with these terms. 